ISSN : 2615-1995, E-ISSN : 2615-0654

J. Madani., Vol. 1, No. 2, September 2018 (431-449)

C2018 Lembaga Kajian Demokrasi

MADANI

dan Pemberdayaan Masyarakat (LKD-PM)

\title{
HUKUM HADIAH AL-FATIHAH KEPADA MAYIT DALAM PERSPEKTIF FIQH MUQARAN
}

\author{
Ahmad Yani Nasution \\ Fakultas Ekonomi, Universitas Pamulang \\ dosen01583@unpam.ac.id
}

\begin{abstract}
Abstrak
Penelitian ini berfokus pada pandangan para ulama empat madzhab mengenai hukum menghadiahkan Al-Fatihah kepada mayit dalam perspektif fiqh muqaran. Menghadiahkan Al-Fatihah adalah kegiatan keagamaan yang dianggap sudah menjadi tradisi di Indonesia. Namun tradisi menghadiahkan AlFatihah ini menjadi sebuah perbincangan yang panas ketika ada kelompok masyarakat yang menganggap tradisi tersebut tidak bermanfaat, bid'ah, bahkan sesat. Tentunya setiap manusia menginginkan setiap amalan yang dilakukan bernilai ibadah yang mendatangkan pahala. Jika dilihat tujuan pensyariatan menghadiahkan Al-Fatihah ini adalah untuk mengirimkan pahala kepada mayit. Jenis penelitian ini adalah kepustakaan yng mengkaji sumber dari kitab-kitab empat madzhab sebagai sumber primer. Selain itu juga digunakan sumber-sumber sekunder dan pendukung yang kemudian diproses secara deskiptif analisis. hasil penelitian ini adalah untuk menemukan bagaimana hukum menghadiahkan Al-Fatihah kepada mayit dari kalangan ulama ditinjau dari empat madzhab. Adapun kitab empat madzhab yang yng digunakan ialah kitab Al-fiqhu 'Ala Mazahib Al-arba'ah, Syarah Aqidah Thohawiyah karya Muhammad bin abil izz, Al-Mughni Ibnu Quddamah, Al-Umm karya Imam besar Syafi'I, Kassyaf al-Qina' karya al-Buhuty dan Mawahibu Al-Jalil. Setelah terkumpul pendapat semua mdzhab, kemudian dikomparasi antara pendapat madzhabb yang satu dengan yang lainnya kemudian dilakukan pentarjihan. Berdasarkan dari hasil analisis dalil yang disebutkan, peneliti berpendapat behwa pahala bacaan Al-Fatihah yang dilakukan oleh orang yang masih hidup akan sampai kepada mayit. Pentarjihan ini peneliti ambil dengan landasan bahwa selama tidak ada nash yang melarangnya maka hal tersebut diperbolehkan. Selain itu landasan tersebut diperkuat dengan adanya pendapat sebagian kalangan Hanafiyah, Malikiyah dan Hanabilah.
\end{abstract}

Kata Kunci: bacaan Al-Fatihah, menghadiahi Al-Fatihah, Empat Mazhab

\section{PENDAHULUAN}

\section{Latar Belakang}

Setiap amalan yang dilakukan dan bernilai ibadah maka akan dibalas pahala oleh Allah SWT. Begitu pula dengan amalan buruk maka akan dihitung sebagai dosa. Disebutkan dalam surat Al-Zalzalah ayat 7 sampai 8: "Barang siapa yang mengerjakan kebaikan seberat zarah pun, niscaya dia akan melihat (balasan) nya. Dan barang siapa yang mengerjakan kejahatan seberat zarah pun, niscaya dia akan melihat (balasan) nya."

Salah satu amalan yang sudah menjadi tradisi di Indonesia adalah penghadiahan pahala bacaan Al-Fatihah dari orang yang masih hidup kepada mayit. Penghadiahan AlFatihah ini dianggap sebagai sebuah ibadah yang dapat mendatangkan pahala untuk mayit meskipun amalan tersebut dilakukan oleh orang lain. Menghadiahkan pahala surat AlFatihah telah menjadi perbedaan khilafiyah, namun demikian permasalahan fiqih khilafiyah 
jangan sampai menjadi cikal bakal perpecahan antara sesama muslim.

Dalam menentukan hukum syarah maupun praktik keseharian fiqih dikaji dan dijadikan rujukan yang kita tahu bahwa kajian fiqh tersebut sangatlah luas. Fikih perbandingan antar mazhab disebut dengan istilah fikh muqaran. Perbedaan pendapat sering terjadi dikalangan fukoha yang selanjutnya menimbulkan hasil ijtihad. Ijtihad ini kemudian dibandingkan yang kemudian disebut sebagai perbandingan madzhab.

Berdasarkan latar belakang ilah penulis merasa perlu menelaah dan meleliti sejauh mana tradisi menghadiahkan pahala AlFatihah kepada mayit dikalangan ulama empat madzhab yang selanjutnya bisa diketahui perbandingannya (perspektif fiqh muqaran). Selanjutnnya penulis berharap hal ini dapat dijadikan pegangan dalam menyikapi berbagai persoalan khilafiyah tradisi tersebut.

\section{Tujuan}

a. Menjelaskan hukum hadiah Al-Fatihah kepada Mayit dalam perspektif fiqh muqaran.

b. Mengetahui penyebab adanya perbedaan pendapat ulama empat mazhab tentang menghadiahkan pahala kepada mayit.

\section{Pembatasan Masalah}

Penelitian ini membatasi masalah mengenai kajian hukum hadiah Al-Fatihah kepada Mayit dalam perspektif empaat madzhab saja, yakni madzhab Hanafi, Maliki, Syafi'i, dan Hambali kemudian dilakukan perbandingannya dalam perspektif fiqh muqaran.

\section{Perumusan masalah}

Rumusan masalah yang menjadi pembahasan pada penelitian ini ialah:

a. Bagaimana perspektif fiqh muqaran dalam membahas hukum menghadiahkan pahala Al-Fatihah kepada mayit.

b. Apa yang menjadi penyebab perbedaan pendapat di kalangan ulama empat mazhab.

\section{Tinjauan Pustaka}

a. Pengertian Hadiah pahala kepada mayit

Hadiah memiliki arti kata pemberian untuk penghargaan atau kenang-kenangan (KBBI) misalny pada sebuah perlombaan atau pertandingan. Abu Hurairah radhiyallahu 'anhu mengatakan bahwasannya Nabi shallallahu 'alaihi wa sallam bersabda:

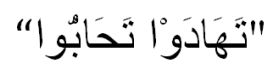

"Salinglah memberi hadiah, maka kalian akan saling mencintai." (HR. Bukhari dalam AlAdab Al-Mufrod, no. 594. Hadits ini dihasankan oleh Syaikh Al-Albani dalam Al-Irwa', no. 1601. Syaikh Musthofa Al-Adawi dalam catatan kaki Fiqh Al-Akhlaq menyatakan bahwa sanad haditsnya hasan dengan syawahidnya.

Dari Imam Zakariya al-Anshari, beliau berkata;

$$
\text { "وينفعه أي الميت من وارث و وغيره و بالإجماع و غيره" }
$$

Sedekah atau doa baik dari ahli waris maupun yang lainnya, bisa bermanfaat bagi mayit dengan sepakat ulama. (Fathul Wahhab, 2/31).

Menurut ensiklopedi islam "pahala" artinya adalah ganjaran atau balasan untuk perbuatan yang baik. Pahala dalam bentuk kata الأجرdalam al-Qur'an disebutkan tidak kurang dari 94 kali dan kata الثوبا sebanyak 9 kali. Sementara pahala dalam bentuk kata أز disebutkan sebanyak 81 kali, termasuk di dalamnya yang menunjuk balasan terhadap perbuatan yang jahat. Definisi pahala dalam bahasa Indonesia adalah ganjaran yang diberikan oleh Tuhan atas perbuatan baik yang dilakukan oleh manusia. Tegasnya, pahala lebih terkait dengan hubungan manusia yang bersifat vertikal, karena autoritas menyangkut pahala itu sendiri hanya semata dimiliki oleh Allah (Nazri, dkk 2011:251).

Dalam al- Quran yang sama-sama diterjemahkan ke dalam Bahasa Indonesia sebagai pahala. Kata yang pertama adalah kata ajr yang di antaranya digunakan dalam QS. al- Baqarah ayat 62 :

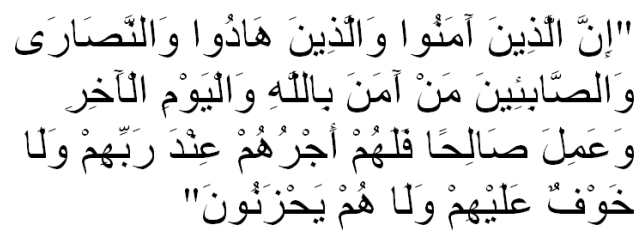

Artinya: "Sesungguhnya orang-orang mukmin, orang-orang Yahudi, orang-orang Nasrani \& orang-orang Shabiin, siapa saja diantara mereka yg benar-benar beriman kepada Allah, hari kemudian \& beramal saleh, mereka akan 
menerima pahala dari Tuhan mereka, tidak ada kekhawatiran kepada mereka, \& tidak (pula) mereka bersedih hati."

Sedangkan kata yang kedua ialah kata śawāb, seperti yang digunakan dalam QS. Ali Imran ayat 145 :

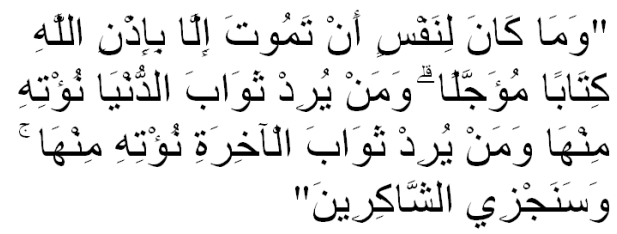

Artinya: "Sesuatu yang bernyawa tidak akan mati melainkan dengan izin Allah, sebagai ketetapan yang telah ditentukan waktunya. Barang siapa menghendaki pahala dunia, niscaya Kami berikan kepadanya pahala dunia itu, dan barang siapa menghendaki pahala akhirat, Kami berikan (pula) kepadanya pahala akhirat itu. Dan kami akan memberi balasan kepada orang-orang yang bersyukur."

Orang yang menghadiahkan pahala dengan orang yang dihadiahkan pahala kepadanya (mayit) biasanya dalam memiliki hubungan sedarah (sekuturunan), seperti orang tua, keluarga dekat atau sanak famili. Tetapi adakalanya ditujukan kepada guru atau bahkan orang lain yang sama sekali tidak ada hubungan kekeluargaan.

\section{b. Hadits Keutamaan Al-Fatihah}

Berikut ini adalah hadits yang menjelaskan keutamaan surat Al-Fatihah:

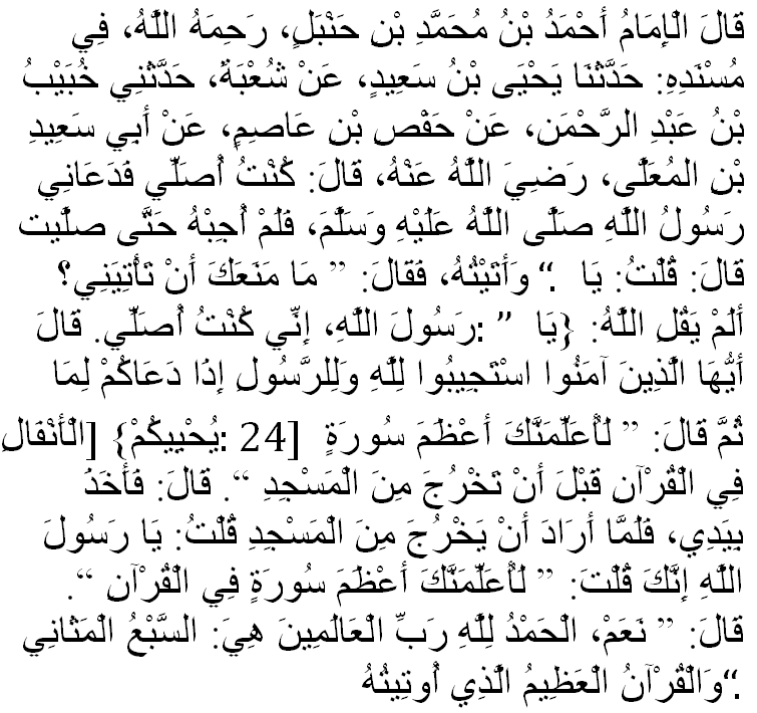

"Imam Ahmad ibnu Muhammad ibnu Hanbal di dalam kitab Musnad-nya mengatakan, telah menceritakan kepada kami Yahya ibnu Sa'id, dari Syu'bah yang mengatakan bahwa telah menceritakan kepadaku Khubaib ibnu Abdur Rahman, dari Hafz ibnu Asim, dari Abu Sa'id ibnul Mua'la r.a. yang menceritakan: Aku sedang salat, kemudian Rasulullah Saw. memanggilku, tetapi aku tidak menjawabnya hingga aku selesai dari salatku, lalu aku datang kepadanya dan ia bertanya, "Mengapa engkau tidak segera datang kepadaku? Aku menjawab, "Wahai Rasulullah, sesungguhnya aku sedang salat"

Kemudian Rasululah SAW bersabda:

"Bukankah Allah Swt. telah berfirman, 'Hai orang-orang yang beriman, penuhilah seruan Allah dan seruan Rasul apabila Rasul menyeru kalian kepada suatu yang memberi kehidupan kepada kalian' (Al-Anfal: 24)"

Kemudian Rasulullah juga bersabda:

"Sesungguhnya aku benar-benar akan mengajarkan kepadamu surat yang paling besar dalam Al-Qur'an sebelum kamu keluar dari masjid ini."

Kemudian Rasulullah SAW memegangi tanganku. Dan ketika hendak keluar masjid aku bertanya kepada Rasulullah SAW: "Ya Rasulullah... sesungguhnya engkau telah mengatakan bahwa engkau akan mengajarkan kepadaku sebuah surat Al-Qur'an yang paling agung. Beliau menjawab, "Ya, Alhamdulillahi rabbil 'alamin adalah sab'ul masani, dan AlQur'anul 'azim yang diberikan kepadaku.'

Mengacu pada kitab Muwatta' karya Imam Malik terdapat sebuah hadits yang berisi:

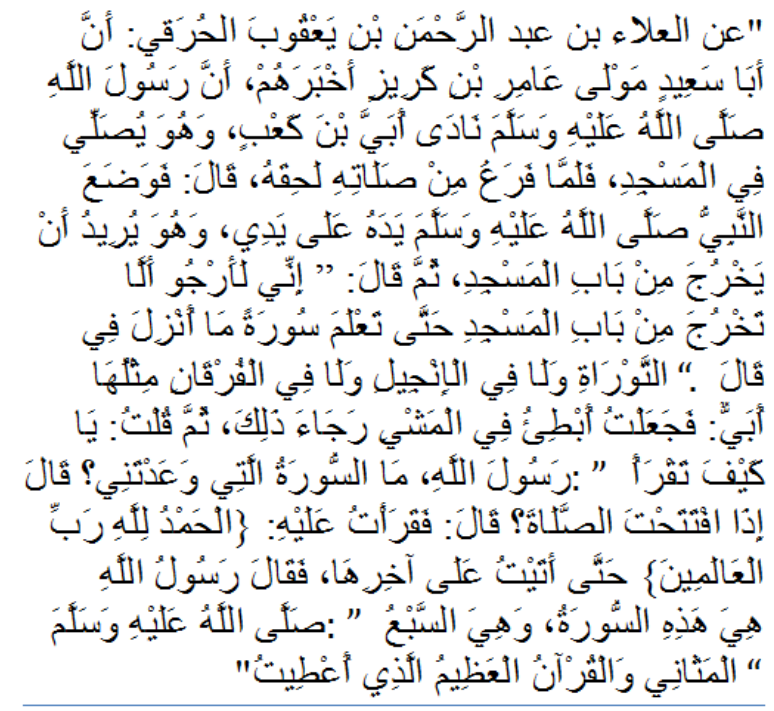

dari Al-Ala ibnu Abdur Rahman ibnu Ya’qub AlHarqi, bahwa Abu Sa’id maula Amir ibnu Kuraiz 
telah menceritakan kepada mereka bahwa Nabi SAW pernah memanggil Ubay ibnu Ka'ab yang saat itu sedang melakukan shalat.

Sesudah Ubay Shalat, lalu ia menjumpai Nabi SAW. Kemudian Nabi SAW memegang tangan Ubay, saat itu beliau hendak keluar menuju pintu masjid. Kemudian beliau Nabi SAW bersabda: "Sesungguhnya aku benar-benar berharap sebelum kamu keluar dari masjid ini kamu sudah mengetahui suatu surat yang belum pernah diturunkan di dalam Taurat, Injil, dan tidak ada pula di dalam Al-Qur'an surat yang serupa dengannya."

Lalu Ubay melanjutkan ceritanya:

"Maka aku mengurangi kecepatan langkahku karena mengharapkan pelajaran tersebut, kemudian aku berkata, 'Wahai Rasulullah, surat apakah yang engkau janjikan kepadaku itu?' Beliau Saw. bersabda. 'Apakah yang engkau baca bila membuka salatmu?' Aku membaca alhamdu lillahi rabbil 'alamin sampai akhir surat,' lalu beliau bersabda, 'Itulah surat yang kumaksudkan. Surat ini adalah sab'ul masani dan Al-Qur'anul 'azim yang diberikan kepadaku."

Pada sanad hadis ini bukanlah Abu Sa'id ibnul Mala seperti yang diduga oleh Ibnul Asir di dalam kitab Jami'ul Usul-ny, namun Abu Sa'id yang terdapat dan orang-orang yang mengikuti pendapatnya. Karena sesungguhnya Ibnul Mala adalah seorang sahabat dari kalangan Ansar, sedangkan Abu Sảid maula ibnu Amir adalah seorang tabi'in, salah seorang maula Bani Khuza’ah (yaitu Abdullah Amir Ibnu Kuraiz Al-Khuza'i). Hadis yang pertama muttasil dengan predikat sahih sementara hadis kedua ini lahiriahnya munqati' jika memang Abu Sa'id tidak mendengarnya dari Ubay ibnu Ka'b. Jika Abu Sa'id benar-benar mendengarnya dari Ubay, maka untuk kebersihannya disyaratkan disebutkan di dalam kitab Sahih Muslim.

Imam Ahmad mengatakan bahwa hadits ini diriwtkan juga oleh Ubay ibnu Ka'b, tidak hanya dari satu jalur saja.

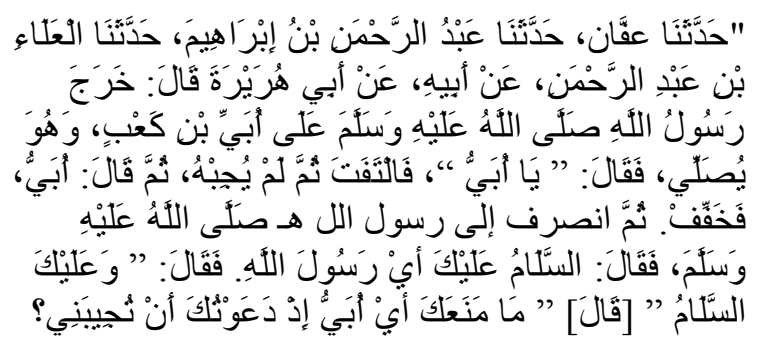

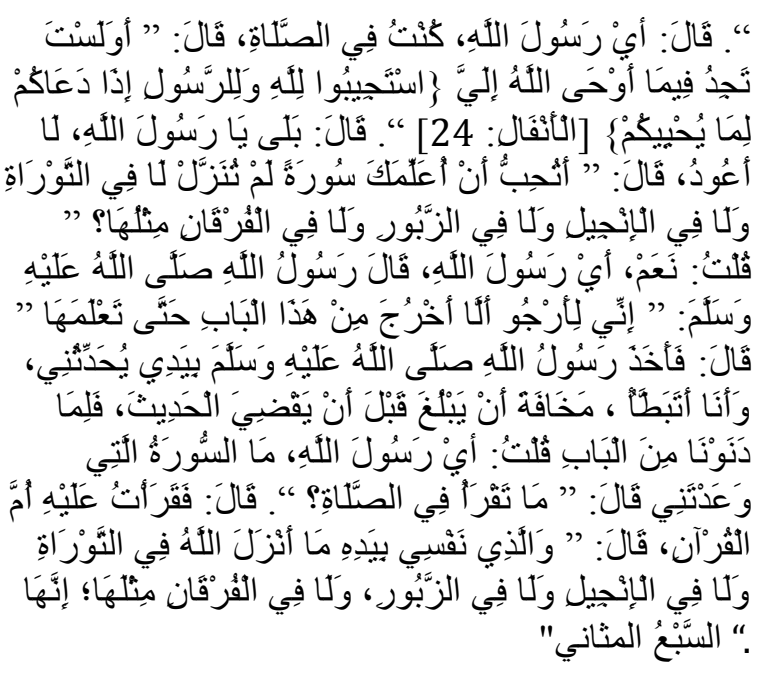

"Imam Ahmad mengatakan, telah menceritakan kepada kami Affan, telah menceritakan kepada kami Abdur Rahman ibnu Ibrahim, telah menceritakan kepada kami Al-Ala ibnu Abdur Rahman, dari ayahnya, dari Abu Hurairah r.a. yang menceritakan bahwa Rasulullah Saw. keluar menemui Ubay ibnu Ka'b yang saat itu sedang salat. Beliau memanggil, "Hai Ubay!" Ubay menoleh, tetapi tidak menjawab, lalu ia mempercepat salatnya. Setelah itu ia segera menemui Rasulullah Saw., lalu bersalam kepadanya. "Assalamu’alaika, ya Rasulallah."

Rasulullah SAW menjawab:

"Wa'alaikas salam, hai Ubay. Apakah yang mencegahmu untuk tidak menjawabku ketika aku memanggilmu?" Ubay menjawab. "Wahai Rasulullah, sesungguhnya aku sedang dalam salatku." Rasulullah Saw. bersabda, "Tidakkah engkau menjumpai dalam apa yang telah diwahyukan oleh Allah kepadaku, bahwa penuhilah seruan Allah dan seruan Rasul apabila Rasul menyeru kalian kepada suatu yang memberi kehidupan kepada kalian? (Al-Anfal: 24)." Ubay menjawab. "Mereka benar, wahai Rasulullah, aku tidak akan mengulanginya lagi".

Rasulullah SAW berkata:

"Sukakah kamu bila aku mengajarkan kepadamu suatu surat yang tidak pernah diturunkan di dalam kitab Taurat. tidak dalam kitab Injil, tidak dalam kitab Zabur, tidak pula di dalam Al-Quran ada surat yang serupa dengannya?"

Ubay menjawab, "Ya, wahai Rasulullah." Rasulullah Saw. bersabda, "Sesungguhnya aku benar-benar berharap, mudah-mudahan sebelum aku keluar dari pintu ini kamu sudah mengetahuinya." Lalu Rasulullah Saw. meme- 
gang tangan Ubay seraya berbicara dengannya, dan Ubay memperlambat langkahnya karena khawatir beliau sampai di pintu masjid sebelum menyampaikan hadisnya. Ketika mereka mendekati pintu tersebut, Ubay bertanya, "Wahai Rasulullah, surat apakah yang engkau janjikan kepadaku itu?" Rasulullah Saw. bertanya. "Surat apakah yang kamu baca dalam salat?" Lalu Ubay membacakan kepadanya surat Ummul Qur'an, sesudah itu beliau Saw. bersabda, "Demi Tuhan yang jiwaku berada dalam genggaman kekuasaan-Nya, Allah tidak pernah menurunkan di dalam kitab Taurat, tidak dalam kitab Injil serta tidak dalam kitab Zabur, tidak pula dalam Al-Qur'an suatu surat yang serupa dengan surat itu (Ummul Qur'an). Sesungguhnya surat itu adalah As-Sab'ul masani."

Imam Turmuzi dari Qutaibah, juga ikut meriwayatkan hadits ini dari Ad-Darawardi, dari Al-Ala, dari ayahnya, dari Abu Hurairah r.a. kemudian Imam Turmuzi mengetengahkan posisi hadis ini, dan pada hadisnya ini terdapat kalimat:

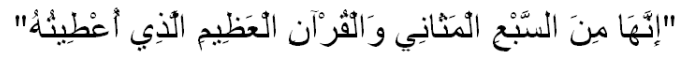

"Sesungguhnya Al-Fatihah ini adalah AsSab'ul masani dan Al-Qur'anul 'azim yang diturunkan kepadaku."

Predikat hadits ini dinyatakan hasan atau shahih oleh Imam Turmuzi, selain itu Anas ibnu Malik. Juga meriwatkan hadits ini dalam bab yang sama.

Abdullah ibnu Imam Ahmad juga meriwatkan hadits ini, dari Ismail ibnu Abu Ma-mar, dari Abu Usamah, dari Abdul Hamid ibnu Ja'far, dari Al-Ala, dari ayahnya, dari Abu Hurairah, dari Ubay ibnu Ka'b, lalu ia mengetengahkan hadis ini dengan panjang lebar, semisal dengan hadis di atas atau mendekatinya.

\section{c. Tujuan Hadiah Al-Fatihah kepada Mayit}

Seseorang yang menghadiahkan pahala amal kepada orang yang telah meninggal, dilatarbelakangi dan didasari oleh beberapa tujuan seperti:

1) Adanya rasa hormat, ta'zhim dan keinginan membalas budi atas jasa dan kebaikan mayit.

2) Diharapkan dengan berkah bacaan Al-
Fatihah tersebut dapat melapangkan kubur dan menerangi kubur.

3) Diharapkan menjadi doa untuk mayit.

\section{d. Pengertian Fiqh Muqaran dan Ruang Lingkup Kajiannya}

Fikih perbandingan antar mazhab disebut dengan istilah fikh muqaran. Berasal dari dua sub kata yaitu fikih dan muqaran. Fiqh berasal dari bahasa Arab, yaitu mashdar dari faqiha, yafqahu, fiqhan yang berarti memahami. Maka setiap orang yang mengetahui suatu ilmu disebut dengan fakih. Sedangkan menurut istilah, fiqh adalah ilmu yang mempelajari hukum-hukum syara' praktis yang diambil dari dalil-dalilnya yang terinci (Ibahim 1991:4-5). Menurut ahli usul, fiqh adalah ilmu yang menerangkan hukum-hukum syara' yang bersifat far'iyah (cabang), yang dihasilkan dari dalil-dalil tafsil (khusus, terinci dan jelas) (Zuhdi 2007:6). Muqaranah adalah isim maf'ul dari qaarana, yuqaarinu, muqaaranatan, muqaarinun yang berarti menghubungkan, mengumpulkan dan membandingkan (Tahido 1997:83). Menurut istilah adalah kata yang berarti membandingkan dua perkara atau lebih (Ramli 1999:7).

Secara etimologi muqaranah seperti dalam kamus munjid karangan Luis Ma'luf adalah berasal dari kata : قارن - يقارن - مقارنة yang artinya mengumpulkan, membandingkan antara dua perkara atau lebih.

Berdasarkan makna lughowi diatas, maka perbandingan mazhab menurut ulama fiqh adalah (Alif 1995:9):

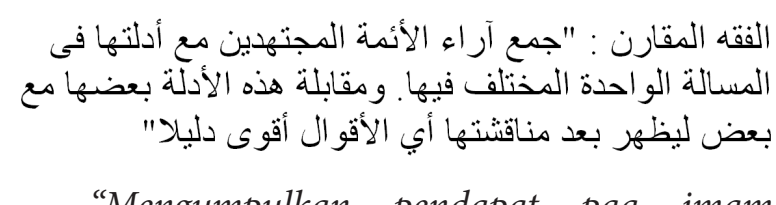

"Mengumpulkan pendapat paa imam mujtahidin berikut dalil-dalilnya tentang suatu masalah yang diperselisihkan, dan kemudian membandingkan serta mendiskusikan dalil-dalil tersebut satu sama lainnya untuk menemukan yang terkuat dalilnya."

Sedangkan pengertian mazhab secara etimologi berasal dari akar kata : yang artinya pendirian atau ar-Ro'yu (pendapat). Selain ituu Kalimat mazhab merupakan isim makan (kata yang menunjukkan tempat). Menurut istilah para ahli bahwa madzhab itu mempunyai dua pengertian yaitu: Pertama : Pendapat salah 
seorang mujtahid tentang hukum suatu masalah dan yang kedua adalah Kaidah-kaidah istimbat (Pengambilan Hukum) yang dirumuskan oleh seorang mujtahid (Orang yang melakukan Ijtihad).

Dapat disimpulkan dari pengertian tersebut bahwa madzhb ialah hasil ijtihad imam mengenai hukum sutu perkara dan masalah maupun mengenai kaidah-kaidah istimbat. Fiqh muqaranah ialah ilmu fiqh yang menghimpun pendapat dari para ulama madzhab mengenai ikhtilaf dalm hukum islam. Kemudian setelah dikumpulkan dilakukan penelitian, pengkajian, serta dalil dari masing-masing pendapat secara objektif sehingga didapatkan pendapat terkuat yang sesuai jiwa, dasar, dan prinsip umum syariah. Selain itu perbanndingan madzhab juga bertujuan untuk mengetahui pesamaan dan perbedaan diantara pendapat-pendapat tersebut, mengambil mana yang terkuat amun tidak keluar makna keaslian dari lughowinya.

Ada empat madzhab yang paling masyhur yakni madzhab Hanafi dari tahun delapan puluh sampai dengan tahun seratus lima puluh hijriyah (80-150 H), Madzhab Maliki dari tahun Sembilan puluh tiga sampai dengan seratus tujuh puluh Sembilan hijriyah (93-179 H), Madzhab Syafíi dari tahun seratus lima puluh sampai dengan dua raus empat hijriyah (150-204H), dan Madzhab Hambali dari tahun seratus enam puluh empat sampai dengan dua ratus emapt puluh satu hijriyah $(164-241 \mathrm{H})$. Selain empat madzhab tersebut, masih banyak madzhab lain seperti : Hasan Bashri, ats-Tsauri, Daud adz-Zhahiri, al-Auza'i, Syiah Imamiyah dan Syiah Zaidiyah (Al-Duraini 1994).

\section{e. Tujuan dan Manfaat Mempelajari Per- bandingan Madzhab}

Adapun tujuan dan manfaat mempelajari perbandingan madzhab adalah sebagai berikut:

1. Mamfaat yang dihasilkan dari belajar perbandingan mazhab adalah untuk mengetahui perbedaan pendapat yang terjadi dikalangan para ulama dalam berbagai macam permasalahan. Kemudian yang tidak kalah pentingnya adalah mengetahui alur berfikir para ulama dalam setiap mengemukakan dalil-dalil yang mereka pergunakan. Pada akhirnya orang yang Mempelajari perbandingan madzhab ini otomatis akan dapat membandingkan pendapat yang satu dengan yang lainnya. Sehingga dengan wawasan yang mumpuni akan menimbulkan kesadaran dan keyakinan yang kuat untuk menjalankan agamanya. terhindar dari panatik atau merasa paling benar karena sudah memperoleh hujjah yang jelas dalam melaksanakan ajaran agamanya. Orang seperti ini tergolong kedalam kelompok yang disebut dalam alquran sebagai berikut:

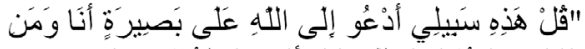

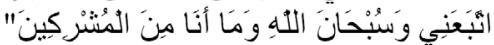

Katakanlah: "Inilah jalan (agama) ku, aku dan orang-orang yang mengikutiku mengajak (kamu) kepada Allah dengan hujjah yang nyata, Maha suci Allah, dan aku tiada Termasuk orangorang yang musyrik".

Dan juga tidak termasuk golongan yang ekslusif seperti dalam alquran berikut ini.

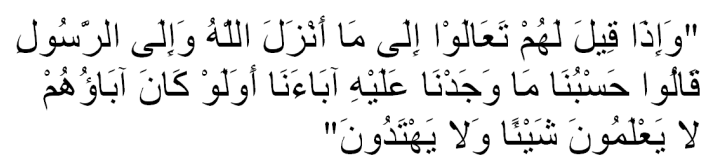

Apabila dikatakan kepada mereka: "Marilah mengikuti apa yang diturunkan Allah dan mengikuti Rasul". Mereka menjawab: "Cukuplah untuk kami apa yang kami dapati bapakbapak kami mengerjakannya". Dan apakah mereka akan mengikuti juga nenek moyang mereka walaupun nenek moyang mereka itu tidak mengetahui apa-apa dan tidak (pula) mendapat petunjuk.

2. Terhindar dari perselisihan dengan yang lainnya karena Dapat merumuskan kaidahkaidah dan dasar-dasar hukum yang dapat diamalkan sesuai dengan hukum Islam itu sendiri.

3. Sebagai alat ukur yang mesti dikuasai agar dapat mengukur imam mazhab dalam istimbat hukum. Ukuran Benar atau salah salah dalam istimbath hukum tergantung seberapa besar kesesuiannya dengan dasar-dasar dan kaidah-kaidah yang berlaku. Secara umum setiap imam madzhab harus tetap berada pada koridor alquran dan alsunnah dalam setiap dalil yang dikemukakannya. Maka dengan demikian seseorang tidak akan pernah merasa paling benar dan mau menghormati pendapat mazhab lain. Inilah sebagai wujud dari pengetahuannya ter- 
hadap fikih perbandingan mazhab. Sebab pada hakikatnya masing-masing ulama tidak terlepas dari aturan ijtihad dalam mengemukakan pendapatnya. Dan tidak kalah pentingnya juga sebagaimana imam mazhab menghormati orang lain seharusnya sebagai pengikut mengikuti imamnya dalam menghormati imam mazhab lain.

4. Jika diperhatikan landasan berfikir para imam madzhab, saat melakukan perbandingan madzhab kita dapat mengetahui dasar-dasar yang digunakan para imam madzhab tersebut yang hakikatnya 'an dan sunnah, pengqiyasan, maslahah mursalah, istishab, dn prinsip umum yang tertuang dalam nash syariah islam. Orang-orang yang mempelajari fiqh muqaranah akan mengetahu bahwa dasar melakukan suatu perkara tersebut berasal dari madzhab lain, bukan dari kalangan non muslim.

5. Dengan mempelajari perbandingan madzhab, terlihat bahwa ilmu fiqh sangatlah luas pembahasnnya dan memiliki khazanah hukum islam yang sebelumnya diwarisi oleh para ulama terdahulu. Sehingga walaupun zaman telah berubah, menjadi zaman yang lebih maju, ebih modern maka semu permasalahan dapat diselesaikan dengan bijak.

Jika kita hanya berpegangan dengan satu madzhab, belum tentu semua masalah yang ditimbulkan dapt terpecahkan. Apalagi jika kita hanya berpegang pada satu macam cara istimbat hukum. Kita perlu membandingkan dengan madzhab lainnya sehingga tidak menimbulkan kesempitan. Firman Allah SWT:

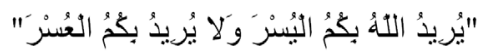

"Allah menghendaki kemudahan bagimu, dan tidak menghendaki kesukaran bagimu."

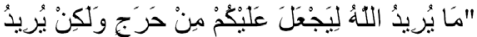

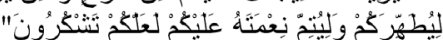

"Allah tidak hendak menyulitkan kamu, tetapi Dia hendak membersihkan kamu dan menyempurnakan nikmatNya bagimu, supaya kamu bersyukur."

Dalam hadis diperintahkan untuk mempermudah jangan mempersulit:
بسروا و لا تعسرو ا و إذا غضب أحدكم فلبسكت (متفق عليه عن أبي هريرة)

"Permudahlah dan jangan kamu persulit, dan apabila marah salah satu diantara kamu, maka hendaklah diam-diam." (Muttafaq 'alaih dari Abu Hurairah).

Ayat dan hadits tersebut menjelaskan adanya kelonggaran dan memberi kebebasan untuk menentukan madzhab mana yang tepat untuk diikuti.

\section{Sebab Munculnya Madzhab}

Kemunculan madzhab disebabkan oleh berbagai hal. Berikut ini adalah rincinnya;

a) Ada banyak perbedaan pendapat atau argumentasi usai wafatnya Rasulullah SAW akan adanya masalah-masalah yang dianggap baru.

b) Daerah kekuasaan Islam makin meluas meliputi semenanjung arab, mesir, irak, Persia, syam, dan lain-lain.

c) Adana perbauran dengan budaya adat istiadat maupun tradisi dengan bangsabangsa lain yang memeluk islam yng telah berhasil ditaklukkan.

d) Adanya jarak yang jauh antar negara-negara yang ditaklukkan oleh pemerintahan Islam. Sehingga para gubenur, qadi/hakim, dan ulama berkeharusan memberikan ijtihad atas jawaban mengenai permasalahan yang dianggap baru.

\section{Sebab-Sebab Terjadinya Ikhtilaf Para Ulama}

Ikhtilaf di kalangan para ulama terjadi disebabkan oleh beberapa sebab yang sulit dihindari, sebagaimana dikemukan Syeikh Mahmoud Syaltout (Ali As-Sayis: 1996:16-17), yaitu:

1. Dalam Al-Qur'an terdapat lafadz-lafadz yang memiliki arti ganda (musytarak), seperti lafadz قرؤ L قرو memiliki arti suci dan haidh. Imam Abu Hanifah, berpendapat, perempuan yang dithalak oleh suaminya harus beriddah tiga kali haidh (قرؤ). Sementara Imam Muhammad bin Idris Asy-Syafi'I, berpendapat, bahwa perempuan yang dicerai oleh suaminya harus beriddah tiga kali suci (قرؤ). Kemudian dalam Al-Quran juga terdapat lafadz hakiki dan majazi, sehingga dalam menetapkan hukum para ulama sering terjadi perbedaan perdapat. 
2. Perbedaan waktu, tempat dan kasus yang dihadapi juga salah satu paktor terjadinya ikhtilaf dalam mengeluarkan hukum. Tidak semua kasus yang dihadapi oleh para ulama, didapatkan nash hukumnya. Sehingga satu-satunya jalan, mereka harus berijtihad. Ketika berijtihad para ulama menggunakan metodologi yang belum tentu sama antara yang satu dengan yang lain. Sehingga menimbulkan hukum yang berbeda-beda pula.

3. Riwayat. Para Ulama tidak sederajad dalam menerima Hadits Rasullah SAW disebabkan jumlah shahabat yang mereka temui tidak sama. Sementara para shahabat juga tidak sederajad dalam mendengar hadits dari Nabi. Ada shahabat yang hanya mendengar satu hadits saja dan ada sampai puluhan, ratusan dan bahkan ribuan hadits. Sehingga ada hadits yang sampai kepada sebahagian ulama dan tidak sampai kepada sebahagian yang lain.

4. Berbeda dalam menggunakan kaedahkaedah ushul dalam menetapkan hukum. Contohnya kaedah: "Perintah setelah larangan hukumnya sunnah." Namun ada kaedah lain: "Perintah setelah larangan hukumnya boleh."

5. Disebabkan adanya dalil yang diperselisihkan menggunakannya, seperti Istihsan, Maslahah Mursalah, Qaul shahabat, 'Uruf, dan lain-lain.

6. Perbedaan kapasitas intelektual masingmasing ulama, tentang masalah-masalah sumber ajaran Islam, terutama dalam bidang hadits Nabi SAW, sehingga ada hadits yang menjadi hujjah bagi sebagian ulama dan ditolak oleh sebagian yang lain.

\section{Istilah-istilah dalam fikih mazhab}

Dalam menjelaskan sebuah hukum masingmasing mazhab mempunyai istilah yang berbeda-beda tapi tidak menutup kemungkinan juga sebuah istilah pada madzhab memiliki pengertian yang sama dengan madzhab lain. Adapun istilah para mazhab (Shalih:2002) adalah sebagai berikut:

\section{Istilah dalam Mazdhab Maliki}

Ada sejumlah istilah yang ada dalam madzhab Maliki:

a. Dalam madzhab Maliki seorang yang memberikan fatwa dengan pendapat yang kuat dalam suatu masalah disebut dengan mufti (madzhab). Sementara yang belum memenuhi syarat mujtahid harus mengambil pendapat yang disepakati di antara mazhab atau mengambil pendapat yang paling dikenal atau yang dikuatkan (tarjih) oleh ulama madzhab pendahulunya.

b. Pendapat-pendapat yang terkuat sampai pendapat di bawahnya antara riwayatriwayat yang ada dikenal dengan istilah. Sebagian Malikiyah. Dalam kitab "al mudawwanah" Perkataan Imam Malik lebih kuat jika dibandingkan dengan pendapat Ibnul Qasim sebaliknya perkataan Ibnu Qasim lebih kuat dibanding dengan perkataan imam yang lain di dalamnya karena beliau adalah orang yang paling tahu dengan madzhab Malikiyah.

c. Istilah al Madzhab adalah sebutan untuk madzhab Maliki.

\section{Istilah Madzhab Syafi'i}

a. seorang mufti madzhab harus menggunakan tarjih ulama madzhab Syafi'i yang terdahulu Jika terdapat dua riwayat pendapat yang berbeda dalam mazhab Syafi'i. Jika pendapat terdahulu tidak ditemukan maka dengan cara tawaqquf (diam). selanjutnya ia harus mengutamakan pendapat yang telah disahkan oleh ulama madzhab yang paling banyak (mayoritas), kemudian yang disahkan oleh yang paling mengetahui tentang madzhab, kemudian paling wara'. Apabila ia tidak menemukan pendapat seperti urutan sebelumnya maka ia mengutamakan yang diriwayatkan oleh Al Buwaithi, Ar Rabi', Al Maradi (686h), Al Muzani. Sementara An-Nawawi (Abu Zakariyah Yahya Ibnu Syaraf An Nawawi), penulis kitab Al-Majmu' Syarah Al-Muhazzab adalah ulama yang menyaring pendapat-pendapat madzhab lengkap dengan penjelasan antara yang rajih dan tidak.

b. Al-Azhhar adalah istilah bagi pendapat yang paling kuat di madzhab Syafi'i.

c. Al-Mashyhur adalah istilah pendapat yang paling terkenal (diikuti lebih banyak orang) dalam madzhab Syafi'i.

d. Al-Ashah yang paling sah dari perkataan Syafi'i berdasarkan dasar-dasar madzhabnya. 
e. Al-Jadid pendapat baru Imam Syafi'i ketika berada di Mesir baik dalam karangan atau fatwah.

f. Al-Qadiim pendapat lama Imam Syafi'i ketika berada di Irak baik dalam karangannya "Al hujjah". yang diamalkan adalah yang madzhab jadid kecuali beberapa masalah saja.

g. Ibnu Hajar mengatakan, tidak boleh talfiq dalam satu masalah seperti seseorang bertaqlid dengan Maliki dalam masalah sucinya anjing dan mengikut Syafi'i dalam mengusap sebagian kepala dalam wudlu untuk melakukan melakukan satu shalat.

\section{Istilah Madzhab Hanbali}

Madzhab Hanbali memiliki Pendapat dan riwayat yang sangat banyak. Terkadang disebabkan karena perbedaan mereka dalam menilai kualitas hadist. Kondisi ini yang menjadikan sebagian mereka memakai ro'yu. Namun demikian perbedaan sering terjadi dalam satu masalah atau karena perbedaan situasi dan kondisi dilapangan. Kemudian Madzhab Hambali berbeda dalam hal mentarjih (menguatkan satu pendapat dari pendapat berbeda). Yaitu :

a. Sebaiknya memperhatikan penukilan perkataan-perkataan yang ada karena itu bukti kesempurnaan agama.

b. Mazhab hambali selalu mengedepankan pendapat Imam Hanbali dalam setiap mentarjih. Jika tidak diketahui sejarah pendapat imam hambali setidaknya ulama mazhab hambali lebih memilih pendapat yang paling kuat dalilnya dan yang paling dekat dengan pendapat imam hambali. Tentunya tanpa mengesampingkan logika Imam Hanbali dan kaidah madzhabnya.

c. Asy Syaikh : guru, jika disebutkan kata ini maka yang dimaksud adalah Ibnu Taimiyah (Syaikhul Islam Abul Abbas Ahmad Taqiyyuddin Ibnu Taimiyah Al Harani) wafat $751 \mathrm{H}$. Jika sebelum masa Ibnu Taimiyah maka yang dimaksud Asy Syaikh adalah Ibnu Qudamah Al Maqdisi (620 h). Jika disebutkan Asy Syaikhani maka yang dimaksud adalah Ibnu Qudamah dan Majduddin Abu Barakat.

d. Asy Syarih yang dimaksud adalah Syamsuddin Abu Faraj Abdur Rahman ibnu Syaikh Abi Umar Al Maqdisi (682 H). e. Al Qadli : Hakim, yang dimaksud adalah $\mathrm{Al}$ Qadli Abu Ya'la Muhammad bin Al Husain bin Al Farra' (458).

f. Abu Bakr yang dimaksud adalah Al Marrudzi $(274 \mathrm{H})$ murid Imam Ahmad.

g. Wa 'Anhu artinya darinya, pengistilahan untuk setiap pendapat yang berasal dari Imam Ahmad.

\section{METODE PENELITIAN Pendekatan Penelitian (Jenis Penelitian)}

Jenis penelitian ini merupakan penelitian kepustakaan/library research, yang menggunakan sumber data berupa literatur baik primer, sekunder, maupun smber pendukung. Data yang didapatkan kemudian dikumpulkan dan diteliti. Setelah itu dilakukan analisis perbandingan antara ijtihad madzhab satu dengan madzhab yang lain yang disebut dengan analisis fiqh perbandingan atau fiqh muqaranah. Dari hasil perbandingan tersebut dilakukan pentarjihan untuk menghasilkan sebuah kesimpulan mengenai ijtihad madzhab dalam menyelesaikan permasalahan ikhtilaf hadiah Al-Fatihah ini.

\section{Sumber Data}

\section{a. Data Primer}

Sumber data primer yang digunakan ialah buku-buku yang menjadi rujukan utama yang berisikan ijtihad dari masing-masing madzhab. Adapun buku-buku yang dianggap mampu menjadi rujukan pimer dalam peneitian ini meliputi buku-buku fiqh madzhab yang empat. Judul-judu 1 buku tersebut diantarana ialah $A l$ fiqh 'Ala Al-Mazahib Al-Arba'ah karya Abdul Rahman Al-Juzairy dan Al-Umm karya Imam Syafi'i.

\section{b. Data Sekunder}

Penulis menggunakan Kitab-kitab fiqih dari ulama empat madzhab sebagai Sumber data sekunder. kemudian ada bebearapa kitab tafsir diantaranya adalah at-Tahbari, Ibnu Katsir dan lainya. dan kitab-kitab hadits terjemah yang termasuk dalam kutub al- Sittah seperti shahih Bukhari yang di-syarah-kan oleh Ibnu Rojab al-Atsqalany, Sunan Ibnu Majah, Shahih Muslim dengan syarah al-Nawawiy, Sunan Abu Daud, sunan al-Nasa'i dan Sunan al-Turmudzi. Selain dari itu ada beberapa kitab hadist lainnya 
seperti Subulussalam karya al-Shan'aniy, Nail al-Athar karya al-Syaukaniy. Dan yang lebih penting semua kitab yang berkaitan dengan fiqih 4 Madzhab. Selebihnya tulisan yang yang menurut penulis ada kaitannya dengan penelitian ini.

\section{c. Teknik Analisis Data}

Penulis mengumpulkan data dari berbagai sumber meliputi kategori primer, sekunder dan pendukung lainnya yang akan diproses secara deskriptif analisis dan konten analisis. Dengan cara seperti ini penulis berharap dapat menemukan bagaimana hukum hadiah AlFatihah kepada mayit dalam perspektif fiqh muqaran.

\section{HASIL DAN PEMBAHASAN}

a. Hukum Hadiah Fatihah menurut Empat Madzhab

Prof. Dr. Zakiah Daradjat menuliskan dalam bukunya yang berjudul Ilmu Fikih bahwa ibadah jika ditinjau dari segi pelaksanaannya terbagi kepada 3 (Daradjat 1995:4), yaitu :

1) Ibadah murni badaniyah, adalah ibadah yang dilakukan dengan mengandalkan gerakan fisik sebagai modal utamanya, seperti shalat, dzikir, puasa, adzan, tilawah atau membaca Al-Qur'an.

2) Ibadah murni maliyah. Adalah semua ibadah yang menjadikan harta sebagai pengorbanan utama. Sebagai contohnya ialah sedekah, infaq, zakat, dan hibah.

3) Ibadah badaniyah maliyah dalah jenis ibadah yang merupakan perpaduan atau gabungan antara ibadah fisik dan ibadah harta. Sebagai contoh ialah umrah, haji, maupun berjihad.

Semua ibadah bisa diwakilkan meurut kesepakatan ulama, seperti ibadah maliyah maupun yang dominan maliyah. Ibadah tersebut antara lain sedekah dan haji. Ataupun ibadah yang secara tegas bisa diwakilakan seperti ibadah puasa yang bisa dihadiahkan pahalanya untuk mayit. Imam Zakariya al-Anshari berkata;

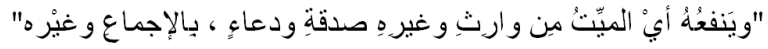

Artinya :"Sedekah atau doa baik dari ahli waris ataupun dari yang lainnya adalah dapat memberikn manfaat kepada mayit menurut kesepakan ulama." (Wahhab dan Al-Anshary 1994).

Keterangan lain disampaikan Ibnu Qudamah,

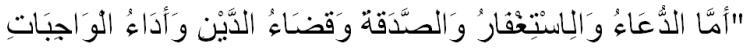

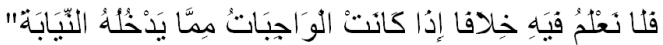

Artinya: "Doa, istighfar, sedekah, melunasi utang, menunaikan kewajiban (yang belum terlaksana), bisa sampai kepada mayit. Kami tidak tahu adanya perbedaan pendapat di kalangan ulama, apabila kewajiban itu bisa diwakilkan." (Kitab Al-Aroby).

Adapun mengenai hukum mengirimkan pahala dari membacakan al-qur'an terdapat perselisihan. Adapun penjabarannya ialah sebagai berikut:

\section{Hukum Hadiah Al-Fatihah Menurut Madzhab Hanafi}

Mengirimkan pahala Al-Fatihah kepada mayit menurut ulama Hanafiyah secara tegas dinyatakan boleh. Pahalanya dianggap akan sampai kepada mayit dan tentunya bisa memberikan mnfaat bagi si mayit. Seseorang dari kalangan Hanafiyah bernama Imam Ibnu Abil Izz menuliskan dalam bukunya sebagai berikut :

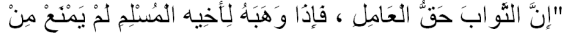

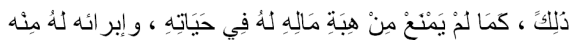

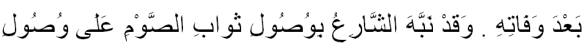

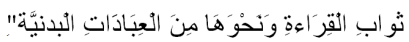

Artinya: "Sesungguhnya pahala adalah hak orang yang beramal. Ketika dia hibahkan pahala itu kepada saudaranya sesama muslim, tidak jadi masalah. Sebagaimana dia boleh menghibahkan hartanya kepada orang lain ketika masih hidup. Atau membebaskan tanggungan temannya muslim, yang telah meninggal."

Telah dijelaskan oleh syariat bahwa pahala puasa bisa dihadiahkan kepada mayit artiny pahala oran yang mengerjakannya akan sampai kepada mayit, yang itu juga memberikan isyarat sampainya pahala dari pembaca Al-Qur'an atau ibadah badaniyah lainnya. 


\section{Hukum Hadiah Al-Fatihah \\ Menurut Madzhab Malikiyah}

Menghadiahkan pahala kepada mayit menurut Imam Malik hukumnya ialah dilarang dan pahalanya dianggap tidak akan sampai tidak memberikan manfaat kepada mayit. Namun demikian, ada sebagian ulama dari kalangan maalikiyah yang justru berpendapt sebaliknya. Hal ini tertuang dengan rinci dalam kitab Minah al-Jalil. Seseorang bernama Imam al-Qarrafi membagi ibadah menjadi tiga,

1. Ibadah yang memberikan pahala dan manfaat yang dibatasi Allah dan hanya berlaku untuk pelaksana ibadah sehingga tidak dapat dihadiahkan atau dipindahkan kepada orang lain pahalanya. Hal ini meliputi padala iman dan yauhid.

2. Ibadah yang pahalanya bisa dihadiahkan dan dipindahkan menurut kesepakatan ulama. Hal yang dimaksud tersebut ialah ibadah maliyah.

3. Ibadah yang masih diperselihkan oleh para ulama apakah ibadah tersebut memberikan manfaat dan bisa sampai kepada mayit atau justru tidak. Contohnya ialah pahala bacaan al-qur'an. Dalam hal ini Imam Malik memberikan lrangannya. (Minan alJalil, 1/509).

Sl-Qarrafi adalah seseorang yang lebih memilih pendapat yang membolehkan, dan ia memberikan pernyataan sebagai berikut:

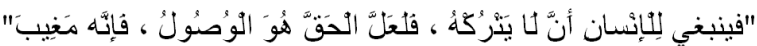

Artinya: "Selayaknya orangtidak meninggalkannya. Bisa jadi yang benar, pahala itu sampai. Karena ini masalah ghaib."

Selain itu terdapat pendapat dari ulama malikiyah yang menyatakan bahwa pahala bacaan Al-Qur'an tidaklah sampai kepada mayit, namun jika yang membaca al-qur'an tersebut membacanya di dekat mayit atu kuburan mayit, maka pahalanya akan sampai karena dianggap mayit tersebut mendengarkan bacaan al-ur'an. Namun hal ini ditolak oleh Al-Qarrafi karena dianggap mayit sudah terputus untuk beramal (Intiqa' At-Taklif) (Minan al-Jalil, 1/510).

\section{Hukum Hadiah Al-Fatihah Menurut Madzhab Syafi'iyah}

Dalam kitab al-Umm Imam Syafi'I mengatakan dengan jelas bahwa beliau suka apabila ada seseorang mau membaca al-Quran di atas kuburan sekaligus berdoa untuk mayit. Adapun pernyataannya sebagai berikut :

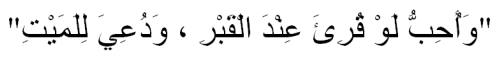

Artinya: "Saya menyukai jika dibacakan alQur'an di kuburnya, dan juga didoakan”.(Kitab Al-Umm: 1990).

Namun dalam kitab lain terdapat Pendapat yang masyhur dari mazhab Syafi'i bahwa tidak sampai pahala bacaan al-Qur'an kepada mayit. Imam An-Nawawi menuliskan dalam kitabnya Syarah Shahih Muslim:

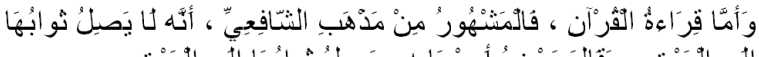

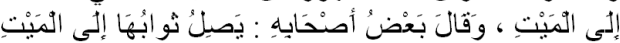

Artinya: "Untuk bacaan al-Quran, pendapat yang masyhur dalam madzhab Syafi'i, bahwasanya pahala bacaaan tersebut tidak sampai kepada mayit. Sementara sebagian ulama syafi'iyah mengatakan, pahalanya sampai kepada mayit."

Hafiz Ibnu Katsir seorang penulis kitab tafsir ayat-ayat hukum, yang merupakan ulama Syafi'iyah yang sngat tegas menyatakan bahwa pahala tersebut tidak akan sampai kepada mayit. Hal ini dapat ditemukan dengan mengikuti firman Allah sebagai berikut:

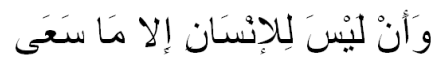

Artinya: "Bahwa manusia tidak akan mendapatkan pahala kecuali dari apa yang telah dia amalkan." (an-Najm: 39).

Ibnu Katsir berkata:

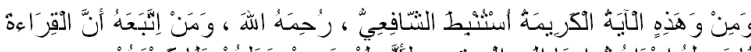

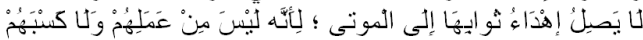

Artinya: "Dari ayat ini, Imam Syafii rahimahullah dan ulama yang mengikuti beliau menyimpulkan, bahwa menghadiahkan pahala bacaan al-Quran tidak sampai kepada mayit. Karena itu bukan bagian dari amal mayit maupun hasil kerja mereka". (Ibnu Katsir 2004:248).

Ini salah satu sebab kenapa Rasulullah SAW tidak menganjurkan dan menekankan kepada 
umatnya dan juga tidak memberikan petunjuk tentang anjuran menghadiahkan bacaan Al-Fatihah kepada yang sudah meninggal dunia. Para sahabat sebagai generasi penerus Rasulullah SAW pun tidak mengajarkan yang demikian. Jika itu sebua kebaikan pasti para sahabat lebih dahulu melakukannya. Berbeda dengan doa dan sedekah yang memang ada nash yang jelas tentang perintah mengamalkannya.

\section{Hukum Hadiah Al-Fatihah Menurut Madzhab Hambali}

Secara umum dalam madzhab hambali terdapat dua pendapat tentang hukum menghadiahkan pahala alfatiha kepada mayit. Pendapat yang pertama Imam Ahmad dan Sebagian ulama hambali mengatakan hukumnya boleh dan pendapat kedua oleh sebagian ulama mazhab hambali mengatakan bahwa hadiah fatiha kepada mayit termasuk amalan yang dilarang Karena tidak ada dalil yang jelas. Sebagaimana yang terjadi pada madzhab Malikiyah. Setidaknya pendapat mazhab hambali pecah menjadi 3 pendapat, Yaitu : Boleh menghadiahkan pahala bacaan al-Quran kepada mayit dan itu bisa bermanfaat bagi mayit. Ini pendapat yang mayhur dari Imam Ahmad.

1. Hukum asal hadiah fatiha kepada mayit tidak diperbolehkan karena tidak akan sampai kepada mayit.

2. al-Buhuty dan mayoritas hambali mengatakan bisa saja pahala sampai kepada mayit dengan syarat harus diniatkan.

3. Melihat pahala adalah milik orang yang melakukan, maka sama saja dengan amalan yang lainnya bisa dihadiahkan

Al-Buhuty berkata:

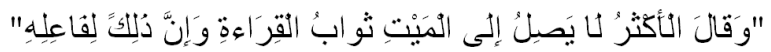

Artinya: "Mayoritas hambali mengatakan, pahala bacaan al-Quran tidak sampai kepada mayit, dan itu milik orang yang beramal".

Dalilnya adalah firman Allah SWT :

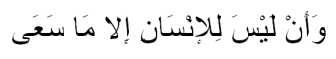

"Bahwa manusia tidak akan mendapatkan pahala kecuali dari apa yang telah dia amalkan." (an-Najm: 39).
Dan juga hadist yang diriwayatkan oleh imam Muslim :

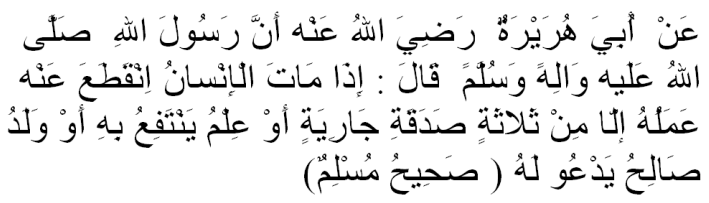

"Apabila Manusia meninggal Dunia maka terputuslah amalnya kecuali karena tiga hal, Shadaqah jariyah, Ilmu yang bermanfaat, atau Anak shaleh yang mendoakannya". (HR. Muslim)

Dari al-Qur'an dan hadist diatas jelas bahwa seseorang tidak akan mendapatkan sesuatu kecuali apa yang telah ia usahakan/lakukan. Begitu juga ketika di hari akhirat nanti seseorng tidak akan mendapatkan ganjaran kebaikan kecuali apa yang ia kerjakan di dunia. Pendapat pertama ini memang mempertegas bahwa tidak ada nash yang menyebutkan tentang sampainya kiriman hadiah alfatihah kepada mayit.

Pendapat kedua adalah pahala bacaan seorang yang muslim akan sampai kepada mayit. Pendapat ini disampaikan oleh sebagian hanabilah. Didalam kitab al-Mughni Ibnu Quddamah menjelaskan pahala semua bentuk kebaikan akan sampai kepada mayit yang dihadiahkan.

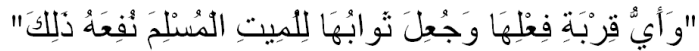

Artinya: "Ibadah apapun yang dikerjakan dan pahalanya dihadiahkan untuk mayit yang muslim, maka dia bisa mendapatkan manfaatnya".

Adapun dalil pendapat yang kedua ini adalah firman Allah :

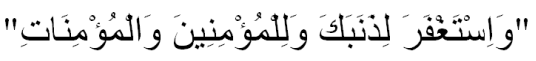

Artinya : "Maka ketahuilah, bahwa sesungguhnya tidak ada Ilah (sesembahan, tuhan) selain Allah dan mohonlah ampunan bagi dosamu dan bagi (dosa) orang-orang mukmin, laki-laki dan perempuan. Dan Allah mengetahui tempat kamu berusaha dan tempat kamu tinggal". (QS Muhammad:19).

Ibnu Qudamah juga menyebutkan pendapat ketiga dalam madzhab hambali, 


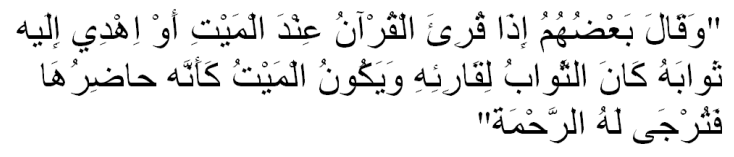

Artinya : "Ada sebagian ulama hambali mengatakan, jika seseorang membaca al-Quran di dekat mayit, atau menghadiahkan pahala untuknya, maka pahala tetap menjadi milik yang membaca, sementara posisi mayit seperti orang yang hadir di tempat bacaan al-Quran. Sehingga diharapkan dia mendapat rahmat".

\section{Penyebab Perbedaan Pendapat Mengenai Hukum Hadiah Al-Fatihah kepada Mayit}

Penyebab terjadinya perbedaan diantara ulama fikih disebabkan perbedaan dalam menggunakan dalil. Sebagian ulama menganggap bahwa hadist tersebut bisa di pahami secara tekstual sementara sebagian ulama lain menganggap bahwa hadist itu tidak bisa di pahami secara tekstual akan tetapi kontekstual. Disisi lain sebagian ulama menganggap hadist tersebut sebagai dalil sementara ulama lain merasa dalil tesebut tidak ada relepansi dengan kasus yang sedang dibahas. Tidak jarang sebagian mereka menganggap bahwa hadistnya dhaif sehingga tidak bisa dijadikan sebagai dasar hukum namun sebagian yang meskipun hadistnya dhaif tetap bisa sebagai dasar hukum karena terdapat hadist pendukung lainnya.

Berdasarkan nash yang sharih atau jelas jumhur ulama sepakat bahwa doa dan pahala sedekah akan sampai kepada mayit. Namun terjadi perbedaan pendapat tentang pahala bacaan alquran. Penyebab terjadinya perbedaan pendapat dalam masalah hadiah pahala bacaan alquran ini dilatarbelakangi oleh penggunaan qiyas. Para ulama yang membolehkan dan berpendapat bahwa hadiah pahala amalan apapun akan sampai kepada mayit dengan mengqiyaskan kepada sampainya amal-amal yang telah disebutkan secara khusus dalam hadits-hadits nabi. Sedangkan para ulama yang menolak dan berpendapat tidak sampai hadiah pahala itu kepada mayit tidak menerima penggunaan qiyas dalam masalah ini, karena menurutnya qiyas tidak berlaku dalam menetapkan hukum-hukum yang berkenaan dengan masalah ibadah.

Adapun dalil-dalil yang dikemukakan oleh masing-masing golongan tersebut adalah sebagai berikut:

\section{a. Dalil-Dalil yang dipergunakan oleh Para Ulama yang Mendukung Sampainya Hadiah Pahala}

Pada dasarnya dalil yang dipergunakan oleh para ulama yang mendukung adanya hadiah pahala kepada mayit adalah ayat-ayat al-Qur'an dan beberapa hadits tentang amalanamalan yang bermanfaat bagi mayit, seperti:

1) Dalil al-quran maupun hadits Rasulullah SAW mengenai sampainya doa dan permohonan ampunan bagi mayit adalah sebagai berikut:

a) "Dan orang-orangyang datang sesudah mereka (Muhajirin dan Anshor), mereka berdoa: "Ya Rabb kami, beri ampunlah kami dan saudara-saudara kami yang telah beriman lebih dulu dari kami, dan janganlah Engkau membiarkan kedengkian dalam hati kami terhadap orang-orang yang beriman; Ya Rabb kami, Sesungguhnya Engkau Maha Penyantun lagi Maha Penyayang." (QS. Al-Hasyr: 10).

b) "Doa seorang muslim kepada saudaranya dari kejauhan (tidak berhadapan) adalah mustajab, di atas kepalanya ada malaikat yang mewakili, setiap mendoakannya dengan kebaikan, berkatalah malaikat yang mewakili itu, 'semoga doa itu dikabulkan, dan bagimu yang semisalnya." (HR. Muslim).

2) Dalil hadits tentang pahala seorang wali baik anak atau ahli waris yang dihadiahkan kepada mayit adalah sebagi berikut: "Dari Aisyah ra. bahwa Rasulullah SAW telah bersabda, "Siapa saja yang meninggal sedang padanya ada kewajiban berpuasa, maka walinya yang menggantikannya." (HR. Bukhari, Muslim, Abu Daud, alBaihaqi, al-Thahawi dan Ahmad)."

3) Dalil hadits tentans pahala sedekah yang sampai untuk mayit diantaranya ialah: "Dari Aisyah ra bahwa ada seorang lakilaki mengatakan, "Ibuku telah meninggal mendadak (tanpa berwasiat sebelumnya), aku mengira bila ia sempat berbicara sebelum meninggalnya, pastilah ia akan bersedekah. Apakah ia akan memperoleh pahala bila aku bersedekah atas namanya (dan pahala pula untukku)?” Beliau menjawab, "Benar". (Lalu orang itupun bersedekah 
atas nama ibunya). (HR. Bukhari, Muslim, Imam Malik, Abu Daud, al-Nasa'i, Ibn Majah, al-Baihaqi dan Ahmad)."

4) Dalil hadits mengenai sampainya pahala haji untuk mayit adlaah sebagai berikut:

"Dari Ibnu Abbas, bahwa ada seorang wanita dari Juhainah yang menemui Nabi seraya berkata: "Ibuku pernah bernadzar untuk menunaikan haji, namun dia belum sempat menunaikannya hingga dia meninggal. Maka apakah aku harus menunaikan atas nama dirinya?" Beliau bersabda, "Tunaikanlah haji atas nama dirinya. Apa menurut pendapatmu sekiranya ibumu masih mempunyai hutang, apakah engkau akan melunasinya? Penuhilah oleh kalian terhadap Allah, karena Allah lebih berhak untuk dipenuhi."

5) Dalil hadits hutang yang dilunasi untuk mayit oleh seseorang yang masih hidup.

Semua musllimin telah menyepakati melunasi hutang dapat menggugurkan tanggungan terhadap hutang mayit. Hutang mayit ini juga bisa dilunasi orang lain atau yang bukan termasuk ahli warisnya, seperti hadist yang ditunjukkan oleh Abu Qatadah, bahwa dia pernah melunasi hutang seseorang yang sudah meninggal sebanyak dua dinar. Setelah hutang itu dilunasi, maka Nabi bersabda, "Sekarang kulitnya terasa dingin olehnya." (HR. AlHakim).

6) Dalil hadits mengenai pahala menyembelih hewan kurban untuk mayit.

Rasulullah SAW saat akan melakukan penyembelihan hewan kurban dua ekor kambing kibas putih, beliau berkta:

"Dengan menyebut nama Allah, Ya Allah terimalah kurbanku dari Muhammad, (pahalanya) untuk keluarga Muhammad dan untuk umat Muhammad. Kemudian beliau menyembelihnya". (HR. Muslim).

Telah menjadi kesepakatan seluruh Kaum muslimin apabila seseorang yang sudah meninggal mempunyai hutang kepada orang lain yang masih hidup maka orang yang masih hidup tersebut bisa membebaskan hutangnya. Ini berarti amalan orang yang masih hidup masih berpengaruh kepada orang yang sudah meninggal.

Jika tanggungan terhadap orang yang masih hidup bisa gugur berdasarkan nash dan ijma', maka maka tanggungan orang yang sudah meninggal lebih layak untuk dapat digugurkan dengan pembebasan tanggungan tersebut, apalagi orang yang sudah meninggal tak mungkin dapat memenuhinya (Ibnu Qoyyim AlJauziyah).

Kemudian para ulama mengqiyaskan sebagai berikut: setiap orang yang melakukan ibadah kebaikan berarti sudah menjalankan haknya untuk beramal. Orang yang beramal berhak mendapatkan pahala. Meskipun demikian tidak ada halangan Jika ia menghadiahkan kepada saudaranya sesama muslim. Sama sekali tidak ada halangan seperti tidak adanya halangan untuk menghadiahkan hartanya selagi dia masih hidup atau membebaskannya setelah dia mati.

Dalil-dalil di atas dan yang semisal diqiyaskan secara mutlak terhadap amal-amal lain yang dengan itu dapat bermanfaat bagi si mayit. Contoh dalam hal ini adalah menghadiahkan alfatiha kepada mayit.

\section{b. Dalil-Dalil yang dipergunakan oleh Para Ulama yang Menolak Sampainya Hadiah Pahala}

Sesungguhnya dalil yang dipakai oleh para ulama yang menolak sampainya pahala al fatiha kepada mayit menggunakan dalil pendapat yang yang pertama. Bedanya pendapat yang pertama menggunakan qiyas sementara pendapat yang kedua tanpa menggunakan qiyas. Adapun dalil mereka sebagai berikut :

1) Firman Allah :

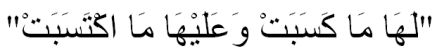

Artinya: "Ia mendapat pahala (dari kebajikan) yang diusahakannya dan ia mendapat siksa (dari kejahatan) yang dikerjakannya". (QS. Al-Baqarah: 286).

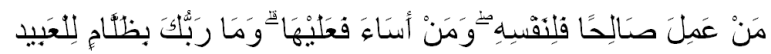

Artinya: "Barangsiapa yang mengerjakan amal yang saleh maka (pahalanya) untuk dirinya sendiri dan barangsiapa mengerjakan perbuatan jahat, maka (dosanya) untuk dirinya sendiri; dan sekali-kali tidaklah Rabb-mu menganiaya hamba-hamba-Nya". (QS. Fushshilat: 46).

2) Hadits Abu Hurairah ra. bahwasanya Rasulullah saw bersabda:

Artinya: "Apabila manusia telah meninggal dunia, maka terputuslah amalnya kecuali 
atas tiga hal: shadaqah jaariyah, atau ilmu yang dimanfaatkan, atau anak shalih yang mendoakannya" [HR. Muslim no. 1631).

3) Ibnu Katsiir dalam Tafsir-nya ketika menafsirkan Surat An-Najm ayat 39 berkata: "Yakni sebagaimana dosa seseorang tidak dapat menimpa kepada orang lain. Demikian juga manusia tidak memperoleh pahala melainkan dari hasil amalnya sendiri. Dan dari ayat yang mulia ini (ayat 39 QS. An-Najm), Imam Asy-Syafi'i dan ulama-ulama lain yang mengikutinya mengambil kesimpulan bahwa bacaan yang pahalanya dikirimkan kepada mayit adalah tidak dapat sampai, karena bukan dari hasil usahanya sendiri.

Oleh karena itu Rasulullah shallallaahu 'alaihi wasallam tidak pernah menganjurkan umatnya untuk mengamalkannya (pengiriman pahala bacaan), dan tidak pernah memberikan bimbingan, baik dengan nash maupun dengan isyarat. Dan tidak ada seorang sahabat pun yang pernah mengamalkan perbuatan tersebut. Kalaupun amalan semacam itu memang baik, tentu mereka lebih dahulu mengerjakannya, padahal amalan pendekatan diri kepada Allah tersebut hanya terbatas pada nash-nash (yang ada dalam Al-Qur'an dan As-Sunnah) dan tidak boleh dipalingkan dengan qiyas-qiyas dan pendapat-pendapat".

Generasi awal mazhab Syafi'i berpendapat menurut pendapat yang masyhur bahwa mayat tidak mendapatkan pahala selain dari balasan amalnya sendiri seperti shalat qadha' yang dilaksanakan untuknya atau ibadah lainnya dan bacaan al-Qur'an. Sedangkan ulama mazhab Syafi'i generasi terakhir menyatakan pahala bacaan al-Qur'an sampai kepada mayat, seperti bacaan al-Fatihah dan lainnya. Demikian yang dilakukan banyak kaum muslimin. Apa yang dianggap kaum muslimin baik, maka itu baik di sisi Allah. Jika menurut hadits shahih bahwa bacaan al-Fatihah itu mendatangkan manfaat bagi orang hidup yang tersengat binatang berbisa dan Rasulullah SAW mengakuinya dengan sabdanya, "Darimana engkau tahu bahwa alFatihah itu adalah ruqyah?". Maka tentulah bacaan al-Fatihah itu lebih mendatangkan manfaat bagi orang yang telah meninggal dunia.

Dengandemikianmakagenerasibelakangan mazhab Syafi'i sama seperti tiga mazhab diatas bahwa pahala bacaan al-Qur'an sampai kepada mayat. Imam as-Subki, sebagaimana yang dikutip oleh Wahbah al-Zuhaili, berkata, "Menurut dalil yang terkandung dalam Khabar berdasarkan istinbath bahwa sebagian alQur'an dibaca dengan niat agar mendatangkan manfaat bagi mayat dan meringankan azabnya, maka itu mendatangkan manfaat baginya, karena menurut hadits shahih bahwa jika surat al-Fatihah itu dibacakan kepada orang yang tersengat binatang berbisa, maka itu bermanfaat baginya dan Rasulullah Saw mengakuinya dengan sabdanya, "Darimana engkau tahu bahwa surat al-Fatihah itu ruqyah?". Jika surat al-Fatihah bermanfaat bagi orang yang masih hidup -jika memang diniatkan untuk itu-, maka tentulah lebih bermanfaat bagi mayat".

\section{Sanggahan Pendapat Kedua Terhadap Pendapat yang Pertama}

a. Kalau memberikan hadiah kepada orang yang sudah meninggal diperbolehkan, maka memindahkan pahala dan menghadiahkannya kepada orang yang masih hidup juga diperbolehkan. Jika hal ini diperbolehkan, maka pemberian hadiah itu bisa separohnya, seperempatnya atau satu qirath (ukuran timbangan tertentu) darinya. Sekiranya hal ini diperbolehkan, maka dia boleh menghadiahkan suatu amal setelah dia mengamalkannya untuk diri sendiri.

b. Hadits tentang orang yang meninggal dunia, sementara dia masih mempunyai tanggungan puasa lalu walinya berpuasa atas nama dirinya, dapat ditanggapi dari beberapa sisi:

1) Malik berkata di dalam muwaththa'nya, "Seseorang tidak bisa berpuasa atas nama orang lain. Ini merupakan pendapat yang menjadi kesepakatan di antara kami."

2) Ibnu Abbaslah yang meriwayatkan hadits puasa yang diatas-namakan orang yang sudah meninggal. Sementara An-Nasa'i juga meriwayatkan dari Ibnu Abbas, dia berkata, "janganlah seseorang shalat atas nama orang lain."

3) Hadits ini diperselisihkan isnadnya. Begitulah yang dikatakan pengarang Al-Mufhim fi Syarh Muslim.

4) Hal ini bertentangan dengan nash al- 
Qur'an, "Dan, bahwa seseorang manusia tidak memperoleh selain apa yang telah diusahakannya." (QS. An-Najm: 39).

5) Hal itu bertentangan dengan hadits riwayat An-Nasa'i, juga dari Ibnu Abbas, dari nabi saw beliau bersabda, "janganlah seseorang shalat atas nama orang lain, janganlah seseorang berpuasa atas nama orang lain, tetapi dia boleh memberi makan atas nama orang lain, yang setiap harinya satu mudd dari biji gandum."

c. Kemudian, sekelompok ulama lain berpendapat dengan mengqiyaskan muslimin pada umumnya dengan orang tua. Menurut Nashiruddin al-Albani, qiyas ini rusak dengan alasan sebagai berikut:

1) Menyalahi makna umum firman-Nya dalam surat al-Najm ayat 39 dan juga firman-Nya, “...Dan barang siapa yang menyucikan dirinya, sesungguhnya ia menyucikan diri untuk kebaikan dirinya sendiri..."

2) Pengqiyasan di sini sangat berbeda dan tidak tepat, disebabkan syariat telah menetapkan bahwa anak merupakan salah satu dari jerih payah usaha orang tua, seperti dijelaskan dalam hadits Aisyah ra. Dan itu bukan merupakan jerih payah orang lain. Sebab Allah SWT telah berfirman: "Tiap-tiap diri bertanggung jawab atas apa yang telah diperbuatnya" (QS. Al-Muddatstsir: 38)

Adapun orang-orang yang berpendapat tentang sampainya berbagai amal kepada orang yang sudah meninggal menanggapi dalil-dalil dan sanggahan di atas sebagai berikut:

a. Kaitannya dengan firman Allah, "Dan, bahwa seseorang manusia tidak memperoleh selain apa yang telah diusahakannya", para ulama berbeda pendapat tentang maksudnya.

1) Ada yang berpendapat, bahwa orang yang dimaksudkan dalam ayat ini adalah orang kafir. Sedangkan orang mukmin mendapatkan pahala dari apa yang diusahakannya dan apa yang diusahakan orang lain bagi dirinya.

2) Ada pula yang berpendapat, firman Allah itu merupakan pengabaran tentang syariat sebelum kita.

3) Ada pula golongan yang berkata, "Huruf lam dalam ayat ini (lil-insan) berarti 'ala (atas). Artinya, tidak ada yang ditimpakan atas manusia melainkan apa yang diusahakannya."

4) Ada pula golongan yang berkata, " $\mathrm{Di}$ dalam pernyataan ini ada ungkapan yang terhapus, yang menjadi kelanjutan, yaitu: Atau yang diusahakan bagi dirinya."

5) Golongan lain berpendapat, bahwa surat al-Najm ayat 39 ini dihapus (dimansukh) dengan firman Allah yang lain, "Dan, orangorang yang beriman dan yang anak cucu mereka mengikuti mereka dalam keimanan, kami hubungkan anak cucu mereka dengan mereka”. (QS. Ath-Thur: 21). Pendapat ini dinukil dari Ibnu Abbas.

6) Ada pula golongan yang berpendapat, bahwa yang dimaksudkan manusia disini adalah orang yang hidup dan tidak termasuk orang yang sudah meninggal.

7) Golongan yang lain berpendapat, dan ini merupakan jawaban yang disampaikan Abul-Wafa' bin Aqil, bahwa manusia dengan usahanya dan

8) Pembuktian dengan sabda Rasulullah, "jika anak Adam mati, maka terputuslah amalnya", tidak tepat. Sebab beliau tidak menyatakan, "Maka terputuslah manfaat yang didapatkan", tapi beliau mengabarkan terputusnya amal. Amal orang lain tetap menjadi milik pelakunya. Jika orang lain tersebut memberikan pahala amal itu kepadanya, maka ia akan sampai kepadanya, dan ini bukan pahala dari amalnya sendiri.

Tentang pernyataan, "Pemberian hadiah itu merupakan pemindahan. Sementara pemindahan hanya bisa terjadi berdasarkan hak yang semestinya", ini merupakan pemindahan makhluk kepada khaliq. Pemindahan makhluk kepada khaliq merupakan masalah lain yang tidak bisa dijadikan qiyas terhadap pemindahan sebagian hamba kepada sebagian hamba yang lain.

b. Tarjih dan Natijah

Fiqh sangat luas pembahasaanya baik dalam menentukan hukum maupun dalam praktik keseharian. Fikih perbandingan antar 
mazhab disebut dengan istilah fikh muqaran. Terdapat banyak perbedaan dalam menentukan hukum karena perbedaan metode berpendapat para fukaha itu sendiri. Perbedaan ini bukan saja terjadi antar mazhab tapi juga terjadi pada mazhab itu sendiri. kumpulan pendapat para ulama dibandingkan dengan ijtihad mazhab lain. Hal ini seritng terjadi dalam menyelesaikan suatu permasalahan hukum. Perbandingan mazhab memuat halhal yang bertalian tentang kedudukan ijtihad dalam Islam, yang didalamnya juga terdapat kajian-kajian tentang sebab-sebab timbulnya perbedaan pendapat tentang hukum Islam dan hikmah serta pengaruhnya dalam kehidupan bermasyarakat.

Mengacu kepada keumuman kaidah ushul fiqh, ibadah terbagi menjadi dua yakni Ibadah Mahdhah (Tidak boleh mengamal kecuali ada nas yang membolehkan) dan Ibadah Ghairu Mahdhah (Boleh mengamalkan kecuali ada nas yang melarangnya). Imam al-Bukhari dan Imam Muslim meriwayatkan bahwa beberapa sahabat Rasulullah SAW pernah singgah di sebuah kabilah, yang kepala sukunya terkena gigitan hewan berbisa. Lalu sahabat melakukan doa ruqyah dengan bacaan Al-Fatihah. Kepala suku pun mendapat kesembuhan dan sahabat mendapat upah kambing. Ketika disampaikan kepada Rasulullah SAW, beliau tersenyum dan berkata:

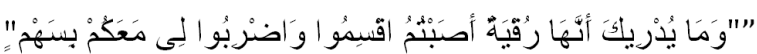

Artinya: "Dari mana kalian tahu bahwa surat Fatihah adalah doa? Kalian benar. Bagikan dan beri saya bagian dari kambing itu" (HR alBukhari dan Muslim)

Dalam hdits ini diceritakan bahwa suatu ketika terdapat seorang sahabat yang membacakan surat Al-Fatihah untuk meruqyah. Padahal hal ini dilakukan tanpa ada perinah dari Rasulullah SW sebelumnya, atau memang murni ijtihad. Namun ternyata Rsulullah SAW sam sekali tidak melarangnya. Disebutkan dalam Al-Quran pada surat Al-Hasyr ayat 7 sebagai berikut:

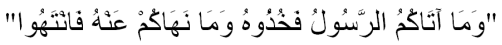

Artinya: “... Apa yang diberikan Rasul kepadamu maka terimalah dia. Dan apa yang dilarangnya bagimu maka tinggalkanlah..."

Melihat hal tersebut dapat disimpulkan bahwa yang harus ditinggalkan ialah apa-apa yang telah dilarang oleh Rasulullah SAW bukan sesuatu yang tidak pernah dilakukan oleh Rasulullah SAW. Para ulama tidak mendapat satupun dari hadist Rasulullah yang berisi tentang larangan membaca Al-Fatiha dan menghadiahkan pahalanya untuk mayit.

Dilihat dari beberapa pendapat yang telah penulis paparkan yaitu tentang hukum menghadiahkan alfatiha kepada mayit maka menurut hemat penulis bahwa hadiah pahala alfatiha sampai kepada mayit. Hal ini memperhatikan pendapat yang telah diutarakan oleh masing-masing mazhab seperti kalangan mazhab hanafi, begitu juga mazhab lainnya, tentang perbedaan pendapat antara generasi lama mazhab syafi'i dan generasi baru. Yang akhirnya mengerucut dengan terdapatnya sebab-sebab perbedaan diantara mereka. Sebab Imam syafi'i sendiri tidak pernah melarang dengan jelas tentang hadiah alfatiha kepada mayit bahkan mengatakan bahwa beliau suka apabila dibacakan alquran di atas kuburan. Selanjutnya setiap pahala yang dihasilkan oleh orang yang melakukannya sepenuhnya akan menjadi miliknya sendiri. Dan orang tersebut berhak memeberikan miliknya dalam hal ini pahala bacaan alfatiha kepada orang lain. Disisi lain dibolehkannya menghadiahkan pahala bacaan alfatiha kepada mayit adalah hadist Rasulullah ketika ziarah kubur. Beliau menyuruh para sahabat untuk memberi salam kepda ahli kubur.

\section{KESIMPULAN}

Setelah penyusun membahas Hukum Hadiah Al-Fatihah kepada Mayit menurut Fih Muqaran, maka dapat ditarik kesimpulan sebagai berikut:

1. Terdapat perbedaan pendapat tentang menghadiahkan alfatiha kepada mayit. Imam abu hanifah dan imam ahmad serta sebagian dari golongan mazhab syafi'i berpendapat bahwa hukum menghadiahkan pahala alfatiha kepada mayit di perbolehkan. Kemudian pendapat yang masyhur dari imam malik dan imam syafi'i berpendapat bahwa menghadiahkan pahala alfatiha tidak sampai kepada mayit. 
Pendapat yang kedua ini berdasarkan QS. An-Najm ayat 39 dan hadist Abi Hurairah tentang jika manusia meninggal dunia maka seluruh amalannya akan terputus kecuali tiga. Sementara pendapat yang pertama mengatakan memang benar al quran dan hadist tersebut tapi setelah diteliti oleh mereka ternyata tidak ada bentuk larangan yang terkandung dalam al quran dan hadist tersebut.

2. Perbedaan tersebut disebabkan karena penggunaan metode yang berbeda dalam mengambil keputusan berpendapat. Pendapat yang mengatakan bahwa boleh menghadiahkan alfatiha kepada mayit mereka menggunakan metode Qiyas. Yaitu menyamakan bacaan al-qur'an dalam hal ini alfatiha dengan ibadah lainnya seperti puasa, haji, membayar hutang yang dapat diwakilkan oleh orang lain. Sementara pendapat yang mengatakan bahwa pahala bacaan al fatiha tidak sampai kepada mayit karena mengambil hukum dari teks QS. An-Najm 39 dan hadist Abi Hurairah.

Dapat dilihat dari berbagai perbedaan pendapat di kalangan ulama. Diantaranya adalah ibadah badaniyah kepada mayit. kita bisa menegaskan bahwa masalah ini termasuk masalah ikhtilaf ijtihadiyah fiqhiyah, dan bukan masalah aqidah manhajiyah (prinsip beragama). Sehingga berlaku kaidah, siapa yang ijtihadnya benar maka dia mendapatkan dua pahala dan siapa yang ijtihadnya salah, mendapat satu pahala.

Dari 'Amru bin Al-Aash radliyallaahu 'anhu: Bahwasannya Rasulullah shallallaahu 'alaihi wa sallam bersabda :

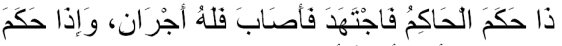

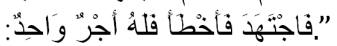

"Apabila seorang hakim menghukumi satu perkara, lalu berijtihad dan benar, baginya dua pahala. Dan apabila ia menghukumi satu perkara, lalu berijtihad dan keliru, baginya satu pahala". (HR. Bukhari 7352 \& Muslim 4584).

Kaitannya dengan ini, ada satu sikap yang perlu kita bangun. ketika kita bersinggungan dengan masalah yang termasuk dalam ranah ijtihadiyah fiqhiyah, yaitu mengedepankan sikap dewasa, toleransi dan tidak menjatuhkan vonis kesesatan. Baik yang berpendapat boleh maupun yang berpendapat melarang.

Setiap orang bebas mengutarakn pendapatnya selama masih berdasarkan alasan dan dalil yang kuat. Kebebasan ini bertujun untuk mengkritik pendapat yang tidk sesui dengannya. Sekaligus mengoreksi pendapat yang berlainan dengannya. Mengkritik dengan menilai sesat merupakan Perlu dibedakan antara mengkritik dengan menilai sesat orang yang lain pendapat. Dalam masalah ijtihadiyah, boleh mengkritik atau mengkritisi pendapat orang lain yang beda, selama dalam koridor ilmiyah, diperbolehkan. Kita bisa lihat bagaiamana ulama yang menyampaikan pendapatnya, beliau sekaligus mengkritik pendapat lain. Namun tidak sampai menyesatkan tokoh yang pendapatnya berbeda dengannya. Tidak jarang kita menemukan orang yang tidak siap untuk di kritik bahkan menganggap dirinya telah dinilai sesat oleh orang lain.

Ketiadaan dalil sharih dalam masalah ini, membuat dalil-dalil yang ada tidak dapat dipadukan (Jam'u) atau dipilih mana yang lebih kuat (Rajih). Oleh karena itu, dalam hal ini penulis memilih pendapat yang mengatakan bahwa pahala bacaan alfatiha akan sampai kepada mayit dengan mempertimbngkan pendapat mayoritas (jumhur) ulama. Namun demikian untuk melakukan suatu ibadah harus mengetahui ilmunya terlebih dahulu dan ibadah tersebut tidak melanggar syariat islam.

\section{DAFTAR PUSTAKA}

Achmad, Zuhdi Dh. 2007. Fiqh Moderat, Sidoarjo: Muhammadiyah University Press.

Ahmad Asy-Syurbasi. 2011. Sejarah dan Biografi Empat Imam Mazhab. Jakarta : Hamzah.

Al duraini. 1994. Moh. Fathii. Buhuutsum Muqaaranah. Syria: Muassasah Al Risalah Bairut.

Al-Anshary, Zakariya. 1994. Fathul Wahhab. 1994. Beirut: Daar fikri.

al-Buhuty. 1987. Kassyaf al-Qina'. Beirut : Alam Kutub.

Alif, Abdul Wahab. 1995. Pengantar Studi Perbandingan Mazhab Cet kedua. Jakarta: Daarul Ulum Press.

al-Zuhaili,Wahbah. 1418 H/1997 M. al-Fiqh alIslamy wa Adillatuhu. Edisi IV. Dar al-Fikr: Damascus.

Armando, Nina M (Ed.), dkk.2005. Ensiklopedi 
Islam. Jakarta: Ichtiar Baru van Hoeve.

Daradjat, Zakiah dkk. 1995. Ilmu Fiqh Jilid I.

Yogyakarta : Dana Bhakti Wakaf.

Departemen Pendidikan Nasional. Kamus Besar

Bahasa Indonesia. Jakarta: Balai Pustaka.

Hasan,Ahmad dkk.1983. Soal - Jawab; Tentang

Berbagai Masalah Agama Cet. VII, h. 993.

Bandung: Diponegoro.

Ibnu Qudddamah. Syarhul Kabir. Mesir : Daar Kitab al-aroby.

Ma'luf, Luis Al-Munjid, Cet ke-16. Beirut: Daar Al-Masyriq.

Muhammad bin 'Alisy. 1989. Manhul jalil $f i$ syarhi mukhtashar kholil. Beirut: Daar fikr.

Muhammad bin abil izz. Syarah Aqidah Thohawiyah jilid. muassah islamiyah.

Muktashar. 2004. Tafsir Ibnu Katsir. Kairo: Maktabah Shafa.

Muslim, Ibrahim.1991. Pengantar Fiqh Muqaranah. Jakarta: Erlangga.

Nazri, Mohd Khairul Nizam Zainan dkk. "The Concept of Rewards and Punishments in quddamah, ibnu. 1985. Al mughni. Mesir: Daar ihya turats.

Ramli. 1999. Muqaranah Mazhahib Fil Ushul. Jakarta: Gaya Media Patama.

Religion: A Special Reference to Kitab Al-Adab of Sahih Bukhari", World Journal of Islamic History and Civilization, Vol. 1, 2011, hlm. 251.

Romli SA. Muqaranah Mazahib fil Ushul. Pamulang: Gaya Media Pratama Jakarta

Shalih,Maryam Muhammad.2002. Musthalahat al mazhahib al fikhiyah. Daar Ibnu Hajm.

Syafi'i,Imam. 1990. Al-Umm. Beirut: Daar Ma'rifah.

Syaltout ,Syeikh Mahmoud dan Syeikh M. Ali As-Sayis. 1996. Perbandingan Mazhab. Jakarta : Bulan Bintang.

Syariffudin, Amir. 2008. Ushul Fiqih. Jakarta : Prenada Media Group

Syekh Muhammad Al-Hudhari Bek, 1387/1968. Tarikh At-Tasyri' Al-Islami. Beirut : Dar AlFikr.

Tahido, Huzaemah .1997. Pengantar Perbandingan Madzhab.Jakarta: logos.

Tim Penyusun KBBI Edisi Kelima. https://kbbi. kemdikbud.go.id/entri/pahala.Diakses pada 15/03/2017.

Wijaro H Sun .1418H. Wijaro H Sun Al Islamiyah Wal Auqof Wal Dakwah Wal Irsyad. Riyad. 